COMPARAÇÃO DE MEMBRANAS PURAS DE 13X E 5A ZEOLITE
PARA REMOÇÃO DE TINTURA LARANJA DE ACRIDINA DE
SOLUÇÕES AQUOSAS

\title{
COMPARISION OF PURE MEMBRANES OF 13X AND 5A ZEOLITE FOR REMOVAL OF ACRIDINE ORANGE DYE FROM AQUEOUS SOLUTIONS
}

\author{
COELLO-FIALLOS, Diana Carolina ${ }^{1 *}$; ESPIN-LAGOS, Segundo Manuel ${ }^{2}$; VACACELA \\ GOMEZ, Cristian ${ }^{3}$; TAVOLARO, Adalgisa ${ }^{4}$; CAPUTI, Lorenzo S. ${ }^{5}$
}
${ }^{1,2}$ Technical University of Ambato, Faculty of Civil and Mechanical engineering (FICM), 180103, Ave Los Chasquis, Ambato-Ecuador. (Phone: +593 032 523039; fax: +593 032 523039)

\author{
${ }^{4}$ Escuela Superior Politécnica de Chimborazo, Physics Research Group, Panamericana Sur K 1 11/2 EC-060155 \\ Riobamba-Ecuador. (Phone: +593 3 299-8200; fax: +593 3 299-8127) \\ ${ }^{3}$ University of Calabria, Surface Nanoscience Group, Department of Physics, 87036, Av Pietro Bucci, Cubo \\ 17C, Rende (CS)-Italy. (Phone: +39 0984 4911; fax: +39 0984496154) \\ ${ }^{4}$ University of Calabria, Institute on Membrane Technology (ITM-CNR), 87036, Via Pietro Bucci, Cubo 33C, \\ Rende (CS)-Italy. (Phone: +39 0984 4911; fax: +39 0984496154) \\ *Autor correspondente \\ e-mail:dc.coello@uta.edu.ec
}

Received 08 December 2017; Accepted 09 December 2017

\section{RESUMO}

Este trabalho foi realizado para testar membranas puras de dois zeólitos $13 \mathrm{X}$ e $5 \mathrm{~A}$ (peneira molecular), como adsorventes efetivos para remoção de corante catiônico, laranja de acridina ( $\mathrm{AO}$ ), a partir de solução aquosa. As membranas foram realizadas por método rápido e fácil sem reagentes adicionais, a membrana pura realizada com $5 \mathrm{~A}$ chamamos de $\mathrm{m}-5 \mathrm{~A}$ e membrana pura realizada com $13 \mathrm{X}$, chamamos $\mathrm{m}-13 \mathrm{X}$. $\mathrm{A}$ adsorção de AO foi estudada em um sistema de lote em conjunto com análises UV-visíveis para determinar a eficiência de $\mathrm{m}-13 \mathrm{X}$ e m-5A, onde ambas as membranas puras apresentaram bons resultados. A influência do tempo de contato na quantidade de corante adsorvido em membranas puras foi investigada, mostra alta redução nas primeiras horas de contato. A eficiência de adsorção é maior usando $\mathrm{m}-13 \mathrm{X}$, às $18 \mathrm{~h}$, atinge $85 \%$, enquanto que para $\mathrm{m}-5 \mathrm{~A}$ atinge $55 \%$. O mecanismo de adsorção foi analisado por modelos cinéticos: Pseudo primeira ordem e Pseudo de segunda ordem, e os dados experimentais mostram que um bom acordo com o modelo de segunda ordem obteve uma quantidade adsorvida de 1,73 e 2,36 mg / g para m-5A e m-13X, respectivamente. Este estudo mostra que o m-13X é um adsorvente mais eficaz que o adsorvente m-5A para remoção de $\mathrm{AO}$ de soluções aquosas.

Palavras-chave: membranas puras, adsorção, laranja de acridina, peneira molecular, modelos cinéticos

\section{ABSTRACT}

This work has been performed to test pure membranes of two zeolites as effective adsorbents for the removal of the cationic dye acridine orange (AO) from aqueous solution. The membranes were made through fast and easy method without additional reagents. Membrane made by $5 \mathrm{~A}$ and $13 \mathrm{X}$ zeolites were called $\mathrm{m}-5 \mathrm{~A}$ and $m-13 X$, respectively. Adsorption of $A O$ was studied in a batch system in conjunction with UV-visible analyses to determine de efficiency of $m-13 X$ and $m-5 A$. Both membranes exhibited good adsorption performance. The influence of contact time on the amount of dye adsorbed onto membranes was investigated, 
showing high reduction in the first hours of contact. The adsorption efficiency after $18 \mathrm{~h}$ was $85 \%$ for $\mathrm{m}-13 \mathrm{X}$, and $55 \%$ for $\mathrm{m}-5 \mathrm{~A}$. The kinetics of adsorption showed good agreement with the pseudo-second order model, giving an adsorbed amount of 1,73 and $2,36 \mathrm{mg} / \mathrm{g}$ for $\mathrm{m}-5 \mathrm{~A}$ and $\mathrm{m}-13 \mathrm{X}$, respectively. This study shows that $\mathrm{m}$ $13 \mathrm{X}$ is a more effective adsorbent than $\mathrm{m}-5 \mathrm{~A}$ for removal of $\mathrm{AO}$ from aqueous solutions.

Keywords: membranes, adsorption, acridine orange, molecular sieve, kinetic models.

\section{INTRODUCTION}

Dyes have a wide use in textile industry and many dyes and their degradation products are toxic and carcinogenic, posing a serious hazard to human health, animals and organisms (Hunger 2007; Crini et al., 2006). The textile industries in Ecuador are a great concern for inappropriate disposal of their effluents into the local water supply.

The removal of synthetic dyes from aqueous solutions is therefore an environmental problem (Brinker et al., 2001). Among the more common processes used for the treatment of wastewater, adsorption is found to be a versatile process and gives good results in the treatment of dyestuff effluents (Moges, et al., 2017; Coello et al., 2015; Monash et al., 2009; Valdés et al., 2009). Many investigations have been performed to develop new adsorbents for the removal of dyes (Wang et al., 2009; Sohrabnezhad and Pourahmad, 2010,). Inorganic materials (e.g. zeolites) with high specific surface areas have been used as alternatives to carbon adsorbents. Sun et al., (2017) presented also solid basis for studying gas adsorption in porous materials.

Zeolites are three-dimensional, microporous, crystalline solids with well-defined structures containing aluminum, silicon, and oxygen in their regular framework. The silicon and aluminum atoms are tetrahedrally coordinated to each other through shared oxygen atoms.

The adsorption properties of zeolites are strongly dependent not only on the pore properties, but also on the chemical and physical properties determined by the synthesis methods and procedures (Tavolaro and Drioli, 1999). Wang and Le Van (2009) obtained similar results for adsorption of $\mathrm{CO}_{2}$ on $5 \mathrm{~A}$ and $13 \mathrm{X}$ zeolites. $\mathrm{CO}_{2}$ adsorption was also investigated on smallpore zeolites Linde $4 A$ and $5 A$, and on $13 X$ zeolites (Mondanari et al., 2011; Sircar et al., 2000; Wang et al., 1998; Kamiuto et al., 2002).

Tavolaro et al. (2011) reported the use of crystalline MFI, FAU, BEA, LTA, MOR, and MEL type zeolite membrane, for cell culture purposes (Tavolaro et al., 2017).

The basic dyes exhibit cationic properties when dissolved in water and react on their basic sides. Acridine orange (AO) dyes is commonly used for textile dyeing (Bath and Rani, 2013), nad is also used to stain tissues (Vanaja et al., 2014; Hunger 2007) and in biology (Alvarez-Buylla et al., 1990).

The removal of $\mathrm{AO}$ has been reported in different investigations (Coello et al., 2015; Palit and Moulik 2003; Çöle et al., 2013; Senthilkumaar et al. 2005). Coello et al. (2015) reported a maximum $A O$ adsorption capacity of $219 \mathrm{mg} / \mathrm{g}$ onto graphene oxide. Lv et al. (2011) studied the adsorption of $A O$ on swelling clays. Photocatalytic degradation was applied on $A O$ using semiconductor $\mathrm{TiO}_{2}$ (Swami and Pandit, 2013). AO was also adsorbed on rye straw, obtaining a maximum adsorption capacity of 208.3 mg/g (Baldikova et al., 2015).

The aim of this work was to study the adsorption efficiency of acridine orange on molecular sieves $13 \mathrm{X}$ and $5 \mathrm{~A}$ in form of pure membrane made by Tavolaro method without chemical modifications.

\section{MATERIALS AND METHODS}

\subsection{Materials}

Zeolites 5A and 13X (Molecular sieve, powder, activated) and dye were purchased from Sigma Aldrich. Acridine orange CAS Number 10127-02-3; linear formula $\mathrm{C}_{17} \mathrm{H}_{20} \mathrm{CIN}_{3} \cdot \mathrm{HCl}$. $1 / 2 \mathrm{ZnCl}_{2}$; molecular weight 369.96 ; dye content of $90 \%$ ) was used without further purification. 


\subsection{Fabrication of zeolite membranes}

The zeolite membranes used in this work as adsorbents were prepared according to the patented Tavolaro et al. method (WO2011098497 A1) with a diameter equal to $13 \mathrm{~mm}$. A zeolite layer was prepared using molecular sieve13X and $5 \mathrm{~A}$; a layer was spread with the desired thickness; the layer was pressed with a pressure of about $2 \mathrm{~kg} / \mathrm{cm}^{2}$ (Tavolaro et al., 2011).

The morphology and structure of the membranes were investigated by Field Emission Scanning Electron Microscopy (FESEM) (FEI QUANTA FEG 400 F7) and Infrared absorption spectroscopy (IR) (Perkin Elmer Spectrum 100 FTIR) using the "Attenuated Total Reflection" (ATR), in the range $4000-450 \mathrm{~cm}^{-1}$.

\subsection{Adsorption}

Adsorption was performed in a batch system and carried out at room temperature (RT $=298 \mathrm{~K}$ ) by contacting pure membranes with 2.5 $\mathrm{mL}$ of dye solutions at different initial concentrations in distilled water.

\subsubsection{Adsorption kinetics}

Each pure membrane was contacted with $2.5 \mathrm{~mL}$ of dye solutions at $100 \mathrm{mg} / \mathrm{L}$ initial concentration. The time contact for kinetic studies was from $1 \mathrm{~h}$ to $48 \mathrm{~h}$, and all tests were performed in static conditions.

Concentration of $A O$ in aqueous solutions was determiner through UV-visible spectroscopy analysis

(Shimadzu

UV-160A spectrophotometer), using the absorbance value at the wavelength of $492 \mathrm{~nm}$. A calibration procedure was applied by using solutions at known concentrations of the three dyes. The adsorption amount $\mathrm{q}_{\mathrm{t}}(\mathrm{mg} / \mathrm{g})$ at time $\mathrm{t}$ was calculated as:

$$
\mathrm{q}_{t}=\frac{\left(\mathrm{C}_{0}-\mathrm{C}_{t}\right) V}{m}
$$

Where, $\mathrm{C}_{o}$ and $\mathrm{C}_{\mathrm{t}}(\mathrm{mg} / \mathrm{L})$ are the initial dye concentration and the dye concentration at time $t(h)$, respectively, $V(L)$ is the volume, and $m(g)$ is the mass of the membrane.

Adsorption efficiency (\%) expressed as a percentage was calculated according to Equation 2:
$\%=\frac{C_{0}-C_{t}}{C_{0}} 100$

\section{RESULTS AND DISCUSION}

\subsection{Characterization of pure membranes}

Figure 1 shows SEM images of the membranes, evidencing a defined and consistent shape. Zeolite membrane are indissoluble and non-disintegrable either by contact or by immersion in water (Tavolaro et al., 2011). The surface of zeolite membranes is plane and smooth with inter-crystalline spaces, pores and cavities with sizes between 2 and $5 \mu \mathrm{m}$.
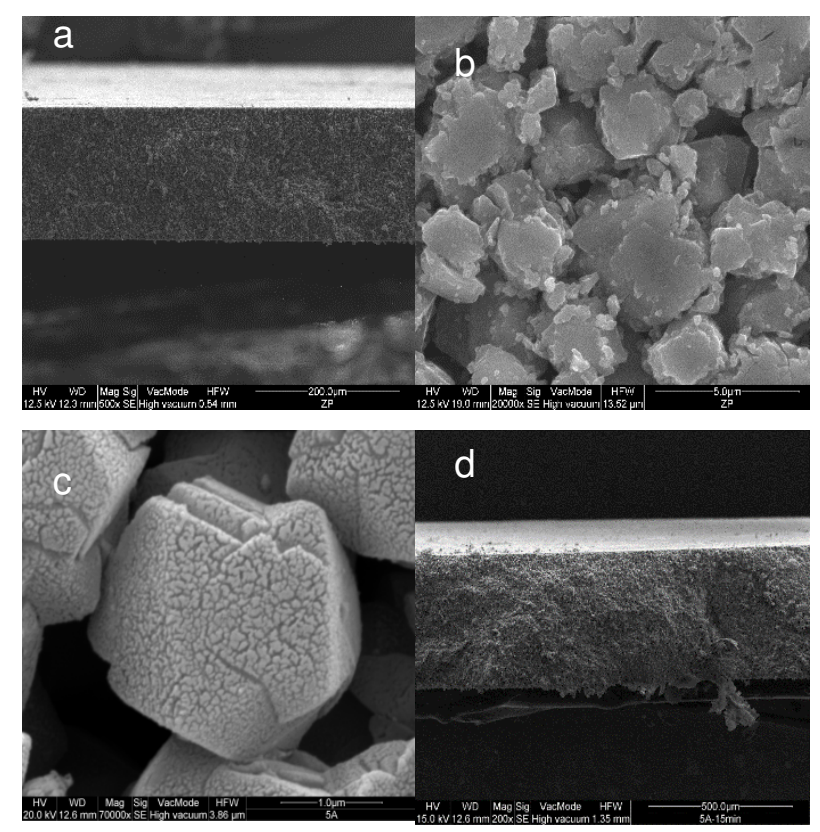

Figure 1. SEM images of pure membranes of zeolites. Cross-sectional morphology of $m-13 X$ and $m-5 A$ in (a) and (d) respectively and surface morphology of $m-13 X$ and $m-5 A$ in (b) and (c) respectively.

SEM image of cross section of $m-13 X$ shows in figure 1a presents a well-defined thickness of the order of hundreds of microns, and well-defined edges. The membrane is characterized by the fact that has an autosupported structure. In figure $1 \mathrm{~b}$ is shown a piece of compressed zeolite 13X with pores and cavities between 3 and $5 \mu \mathrm{m}$. Thickness of $\mathrm{m}-5 \mathrm{~A}$ is of several hundreds of microns (figure 1d), with some pores between the crystals of around $2 \mu \mathrm{m}$ of diameter (figure 1c) and rough particles. 
FTIR spectra of pure membranes are shown in figure 2 , with the characteristic bands for zeolite $\mathrm{Na}-\mathrm{X}$, and present similar bands for $\mathrm{m}$ $5 \mathrm{~A}$ and $\mathrm{m}-13 \mathrm{X}$ due to $\mathrm{OH}, \mathrm{C}-\mathrm{O}, \mathrm{C}-\mathrm{H}$ and $\mathrm{C}-\mathrm{C}$ functional groups. The $\mathrm{m}-5 \mathrm{~A}$ spectrum shows an additional band at $1475 \mathrm{~cm}^{-1} \quad(\mathrm{C}=\mathrm{C}$ ring breathing), and the band at $556 \mathrm{~cm}^{-1}$ (stretching $\mathrm{C}-\mathrm{O}$ ) is more intense that in $\mathrm{m}-13 \mathrm{X}$ spectrum, while the band around $700 \mathrm{~cm}^{-1}$ is more intense in $\mathrm{m}-13 \mathrm{X}$
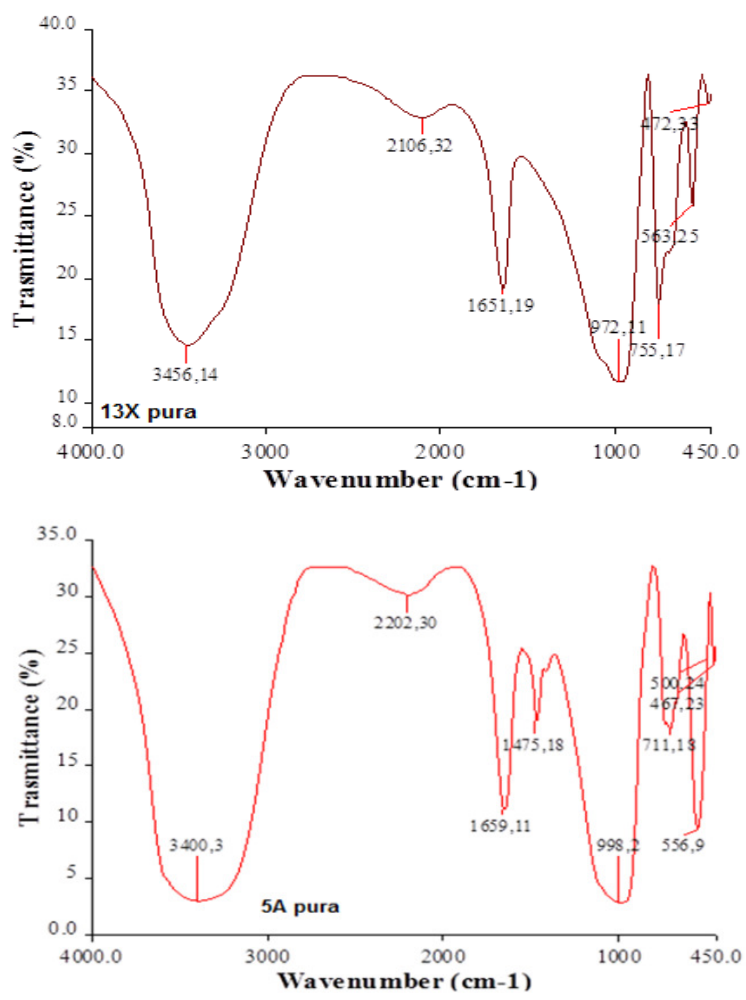

Figure 2. FTIR-ATR spectra of pure membranes $m-13 X$ (upper) and $m-5 A$ (down) recorded from 4000 to $450 \mathrm{~cm}^{-1}$

\subsection{Adsorption}

Pure membrane $m-13 X$ and $m-5 A$ are able to adsorb the pollutants because evidenced additional porous between the crystals. Adsorption capacity is the accumulation of the solute molecules of dye at the surface of the pure membranes. This capacity is directly proportional to the area of the surface exposed and is dependent on the solute partial pressure and the temperature.

Fig. 3 shows the adsorption capacity and efficiency of $m-13 X$ (a) and $m-5 A$ (b) as a function of time, with an initial concentration of $100 \mathrm{mg} / \mathrm{L}$.
The influence of contact time was studied in a range from 1 to $48 \mathrm{~h}$. In the first 8 hours a fast adsorption took place, followed by a slower adsorption. The adsorption was higher using $\mathrm{m}$ $13 \mathrm{X}(85 \%$ after $18 \mathrm{~h})$, with respect to $\mathrm{m}-5 \mathrm{~A}(65 \%$ after $18 \mathrm{~h}$ ). The results indicate that adsorption proceeds with different rates and that $m-13 X$ is a better adsorbent than m-5A.

(a)

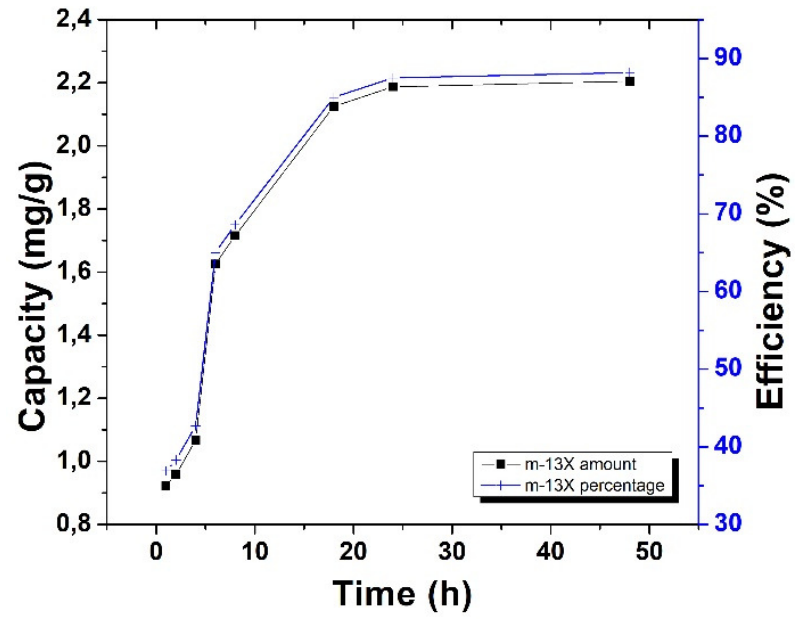

(b)

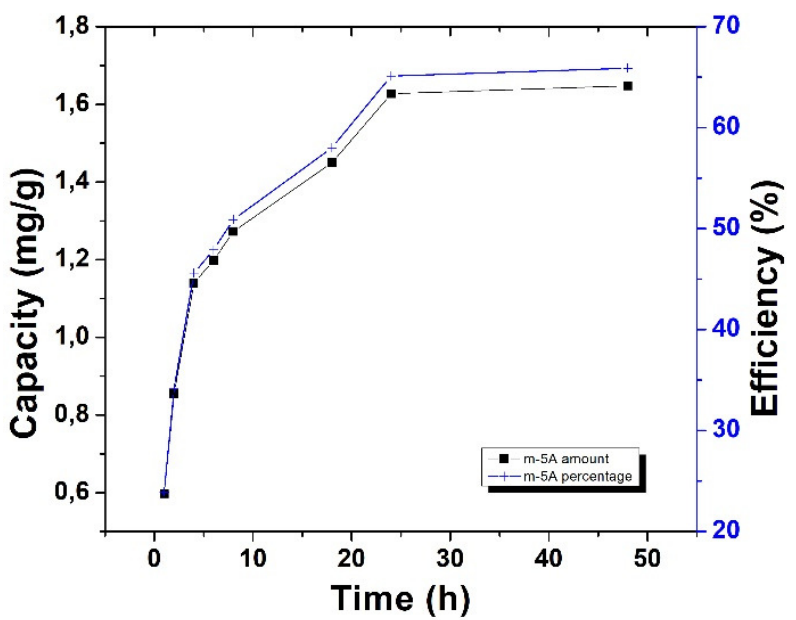

Figure 3.Adsorption capacity and efficiency of pure membranes to remove $A O, m-13 X$ (a) and $m-5 A(b)$.

\subsubsection{Kinetics adsorption models}

In order to examine the adsorption mechanism, the kinetics processes were analysed for both pure membranes using two models. The pseudo-first order is expressed in equation 3. 
$\ln \left(q_{e}-q_{t}\right)=\ln q_{e}-k_{1} t$

where $q_{e}(\mathrm{mg} / \mathrm{g})$ is the amount of dye adsorbed at equilibrium, $q_{t}(\mathrm{mg} / \mathrm{g})$ is the amount of dye adsorbed at time $t$, and $k_{1}\left(h^{-1}\right)$ is the first order rate constant.

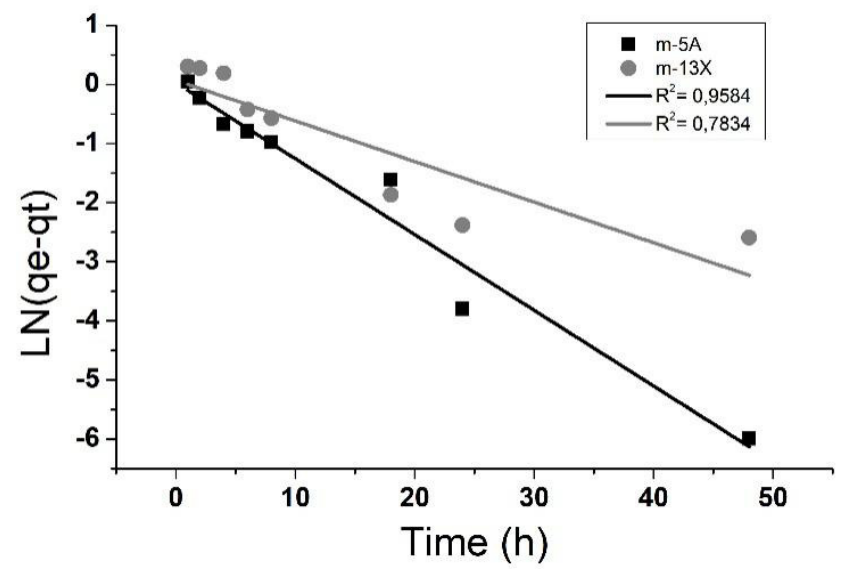

Figure 4. Pseudo-first order fit of adsorption of AO by $m-13 X$ and $m-5 A$.

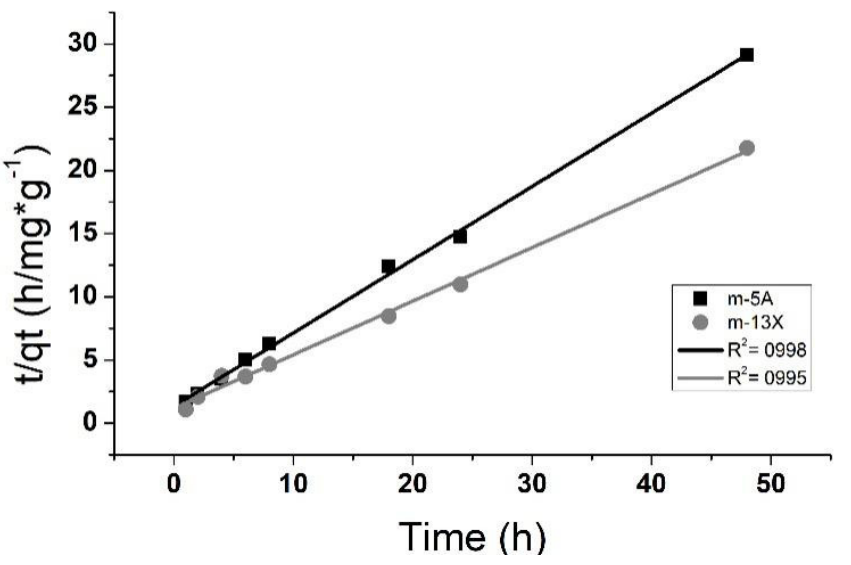

Figure 5. Pseudo-second order fit of adsorption of $A O$ by $m-13 X$ and $m-5 A$.

The pseudo-second order model is expressed by the following equation:

$\frac{t}{q_{t}}=\frac{1}{K_{2} q_{e}^{2}}+\frac{1}{q_{e}} t$

where $q_{e}$ and $q_{t}(\mathrm{mg} / \mathrm{g})$ have the same meaning as above, and $\mathrm{k}_{2}(\mathrm{~g} / \mathrm{mg} / \mathrm{h})$ is pseudosecond order rate constant.
Plot of equations 3 and 4 would confirm the applicability of the models. The application of the pseudo-first order model for $\mathrm{m}-13 \mathrm{X}$ and $\mathrm{m}-5 \mathrm{~A}$ are show in Figure 4. The experimental values of adsorption seem quite far from the fitting conditions for both pure membranes. On the contrary, the plot of t/qt versus $t$ in Fig. 5 (pseudo-second order model) exhibits a linear behaviour, showing that the pseudo-second order model is valid for both membranes.

Table 1 shows the parameters of the fittings made for the two membranes. Different studies have been published about the impact of several influential parameters such as contact time, initial dye concentrations, using different kinetic models (Rabiti et al., 2016; Khosla, 2016; Kuisma et al., 2016). The parameters shown in Table 1 confirm that the adsorption of $\mathrm{AO}$ onto our $m-13 X$ and $m-5 A$ is well fitted by the pseudosecond order kinetic model.

Table 1. Parameters of kinetic models obtained for $m-13 X$ and $m-5 A$ adsorbent

\begin{tabular}{l|rrr|rrr}
\hline & \multicolumn{3}{|c|}{$\begin{array}{l}\text { Pseudo-first } \\
\text { order }\end{array}$} & \multicolumn{3}{c}{$\begin{array}{c}\text { Pseudo- } \\
\text { second order }\end{array}$} \\
\hline & $\mathrm{R}^{2}$ & $\mathrm{qe}$ & $\mathrm{k} 1$ & $\mathrm{R}^{2}$ & $\mathrm{qe}$ & $\mathrm{k} 2$ \\
\hline & 0,958 & 1,027 & 0,128 & 0,998 & 1,725 & 0,249 \\
$\mathrm{~m}-5 \mathrm{~A}$ & 4 & 5 & 2 & 2 & 5 & 1 \\
$\mathrm{~m}-$ & 0,783 & 1,074 & 0,068 & & 2,358 & 0,152 \\
$13 \mathrm{X}$ & 4 & 7 & 7 & 0,995 & 9 & 4 \\
\hline
\end{tabular}

\section{CONCLUSIONS}

Our work was performed to test pure membranes of $13 \mathrm{X}$ and $5 \mathrm{~A}$ molecular sieves to remove $A O$. The results showed rapid adsorption on the two membranes. The equilibrium was reached in similar time, but the adsorption capacity of $m-13 X$ was higher that $m-5 A$. In both cases, the adsorption kinetics was well fitted by the pseudo-second order model. Both pure membrane can be used for an efficient removal of $\mathrm{AO}$ dye from aqueous solutions.

\section{ACKNOWLEDGEMENTS}

The author thank the financial support of Secretary of Higher Education Science Technology and Innovation (SENESCYT), and of PON R\&C (Programma Operativo Nazionale Ricerca e Competitività 2007-564 2013) project Pon_01 00293 "SPREAD BIO-OIL". 


\section{REFERENCES}

1. Alvarez-Buylla, A., Ling, C. Y., Kirn, J. R. J. Neurosci. Meth.1990, 33, 129.

2. Baldikova, E. Safarikova, M. Safarik, I. J. Magn. Magn. Mater. 2015, 380, 181.

3. Bhatt, P., Rani, A. Asian Dye. 2013, 10, 51.

4. Brinker, C. J.; Cornils, B.; Bonet, M. Ullmann's Encyclopedia of Industrial Chemistry, Wiley-VCH: New York, 2001, 6th ed.

5. Çöle, G., Gök, M. K., Güçlü, G. Water Air Soil Pollut. 2013, 224, 1.

6. Coello-Fiallos, D.; Vacacela-Gomez, C.; Tubón-Usca, G.; Cid-Perez, D.; Tavolaro, D.; Martino, G.; Caputi, L.; Tavolaro, A. J. AIP Proc. 2015, 1646, 38.

7. Crini, G. Bioresour. J. Technol. 2006, 97, 1061.

8. Hunger, K. Industrial Dyes 2007, pp. 5-6540.

9. Kamiuto, K., Abe. S, Ermalina, S. Appl. Energy, 2002, 72, 555.

10. Khosla, E. Chem. Applied Biochem. 2016, 2, 57.

11. Kuisma, E.; Hansson, C. F.: Lindberg, T. B.; Gillberg, C. A.; Idh, S.; Schröder, E. J. Chem. Phys. 2016, 144.

12. Lv, G., Li, Z., Jiang, W. T., Chang, P. H., Jean, J. S., Lin, K. H. J. Chem. Eng.

2011, 174, 603.

13. Moges, M.E., Todt, D., Eregno, F.E., Heistad, A. Ecol. Eng. 2017, 105, 118.

14. Monash, P.; Pugazhenthi, G. J. Adsorption 2009, 15, 390.

15. Montanari, T., Finocchio, E., Salvatore, E., Garuti, G., Giordano, A., Pistarino, C., Busca, G. Energy, 2011, 36, 314.

16. Palit, D., Moulik, S. P. Coll. J. 2003, 65, 350.

17. Robati, D.; Mirza, B.; Rajabi, M.; Moradi, I. Tyagi, S. Agarwal, and V. K. Gupta O., Chem. Eng. J. 2016, 284, 687.

18. Senthilkumaar, S., Porkodi, K., Vidyalakshmi, R. J. Photoch. Photobio A: Chem. 2005, 170, 225.

19. Sircar, S. and Golden TC. Sep Sci. Technol, 2000, 35, 667.

20.Sohrabnezhad, Sh. Pourahmad, A. J. Desalination 2010, 256, 84.

21. Sun, L., Yang, L., Zhang, Y., Shi, Q., Lu, R.F., Deng, W. Q. J. Computational.
Chem. 2017, 38, 1991.

22. Swami, D., Pandit, P. Nat. Environ. Pollut. Technol. 2013, 12, 517.

23. Tavolaro, P., Catalano, S., Martino, G., Tavolaro, A. App. Surf. Sci. 2017, in press.

24. Tavolaro, A., Drioli, E. J. Adv. Mater. 1999, 11, 975.

25. Tavolaro, A., Martino, G., Tavolaro, P. 2011, Patent WO 2011098497 A1.

26. Vanaja, M., Paulkumar, K., Baburaja, M., Rajeshkumar, S., Gnanajobitha, G., Malarkodi, C., Sivakavinesan, M., Annadurai, G. Bioinorg. Chem. Appl. 2014, 2014, 1.

27. Valdés, H., Tardón, R., Zaror, C. Revista chilena de ingeniería, 2009, 17, 360.

28. Wang, C., Li, J., Wang, L., Sun, X., \& Huang, J. Chinese J. Chem. Eng. 2009 17, 513.

29. Wang, Y. and Le Van, M. D. J. Chem. Eng. Data, 2009, 54, 2839.

30. Wang, Z.M., Arai, T., Kumagai, M. Energy Fuels, 1998, 12,1055. 